\title{
The Effects of Gilmer: \\ Empirical and Other Approaches to the Study of Employment Arbitration
}

\author{
STEPHEN J. WARE*
}

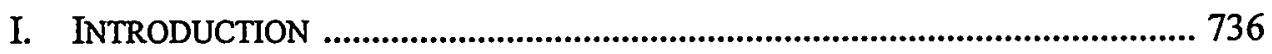

II. EMPLOYMENT ARBITRATION DEFINED ………........................................ 737

A. Employment Distinguished from Labor ................................................ 737

B. Employment Arbitration Law ..................................................................... 737

III. EFFECTS OF AN EMPLOYMENT DISCRIMINATION STATUTE ........................ 740

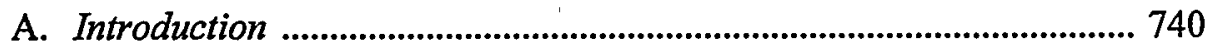

B. Universal Employment Mandates ........................................................... 741

C. Targeted Employment Mandates ........................................................... 742

1. Generally ............................................................................................... 742

2. Binding and Non-Binding

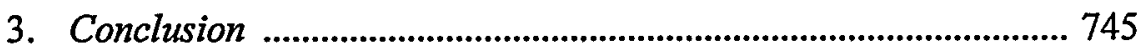

IV. EFFECTS OF EMPLOYMENT ARBITRATION …........................................... 746

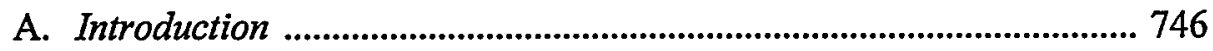

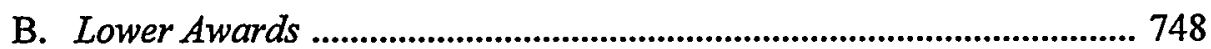

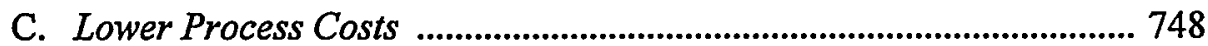

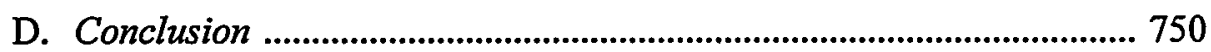

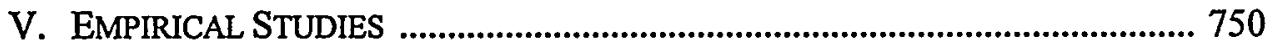

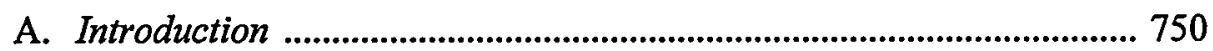

B. The Repeat-Player Effect and Those Who
Make Too Much of It .................................................................... 751

C. Studies Comparing Employment Arbitration and Litigation ............... 753

D. Warning! Use Empirical Studies with Care! ......................................... 755

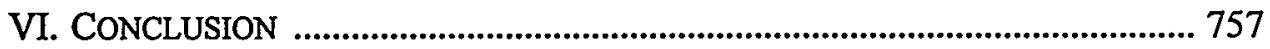

* Professor of Law, Samford University, Cumberland School of Law. Thanks to Christine Jolls, Doug Cole, Sarah Rudolph Cole, Bruce Adelstein, Chris Drahozal, Jean Sternlight, Alan Rau, Keith Hylton, Richard Bales, Lew Maltby, Michael Heise, and Susan Nielsen. 


\section{INTRODUCTION}

This article explores the effects of a particular legal rule. The rule is that employees' pre-dispute arbitration agreements are enforceable "save upon such grounds as exist at law or in equity for the revocation of any contract." I This rule is embodied in a 1991 Supreme Court case, Gilmer v. Interstate/Johnson Lane Corp., ${ }^{2}$ and lower court cases applying and extending it. ${ }^{3}$

The Gilmer rule is quite controversial. Many Gilmer opponents charge that the Gilmer rule harms employees. ${ }^{4}$ In contrast, Gilmer's proponents praise its rule as beneficial to employees. ${ }^{5}$ Both groups rely on empirical studies in making these assertions. ${ }^{6}$ These studies, however, are at best inconclusive on whether the Gilmer rule benefits or harms employees. ${ }^{7}$ Both sides in the employment arbitration debate have been too quick to claim that their views are supported by the empirical evidence. In the employment arbitration debate, as in other debates, we should be skeptical of declarations that empirical studies "prove" one side of the debate to be correct.

Recognizing the inconclusiveness of existing empirical studies of employment arbitration, some commentators call for more such studies. ${ }^{8}$ This may, however, throw good money after bad. Empirical studies are vulnerable to the possibility that the studied cases going to arbitration are systematically different from the studied cases going to litigation. ${ }^{9}$ For this reason, empirical studies are, at best, an incomplete path toward understanding the effects of the Gilmer rule.

19 U.S.C. $\$ 2$ (1994 \& Supp. 2000).

2 Gilmer v. Interstate/Johnson Lane Corp., 500 U.S. 20 (1991).

3 See infra notes 22-23.

${ }^{4}$ See infra notes 24-25.

5 See infra note 93.

6 See infra Part V.

7 Id.

${ }^{8}$ E.g., Michael Z. Green, Debunking the Myth of Employer Advantage From Using Mandatory Arbitration for Discrimination Claims, 31 RUTGERS L.J. 399, 443 n.158 (2000).

${ }^{9}$ Id. 


\section{EMPLOYMENT ARBITRATION DEFINED}

\section{A. Employment Distinguished From Labor}

Employment law is customarily distinguished from labor law. "Employment law" applies to all employees, while "labor law" applies only to employees represented by a labor union. ${ }^{10}$ The employment/labor distinction is also central to the terminology of arbitration. "Employment arbitration" arises out of a contract between an employer and an individual employee, while "labor arbitration" arises out of a collective bargaining agreement between an employer and a union. Employment arbitration is the subject of this article. This article does not directly address labor arbitration, which is governed by a very different set of laws and practices, ${ }^{11}$ but much of its reasoning applies equally in the labor context.

\section{B. Employment Arbitration Law}

Employment arbitration is governed primarily by the Federal Arbitration Act (FAA). ${ }^{12}$ Enacted in 1925, the FAA is resolutely pro-contract. Section 2 of the FAA provides that arbitration agreements are enforceable "save upon such grounds as exist at law or in equity for the revocation of any contract." 13 This language reflects an intent to place arbitration agreements "upon the same footing as other contracts" and to reverse judicial hostility to the enforcement of arbitration agreements. ${ }^{14}$ The FAA's enactment was

10 Comparing the Hornbooks on Employment Law and Labor Law highlights this point. See generally ROBERT A. GORMAN, BASIC TEXT ON LABOR LAW: UNIONIZATION AND COLlECTIVE BARGAINING (1976); MARK A. ROTHSTEIN ET AL., EMPLOYMENT LAW (2d ed. 1999).

11 See, e.g., IAN R. MACNEIL ET AL., FEDERAL ARBITRATION LAW § 11.3.1 (1997); Stephen J. Ware, Employment Arbitration and Voluntary Consent, 25 HOFSTRA L. REV. 83, 90-94 (1996). For discussions of labor arbitration, see FRANK ELKOURI \& EDNA ASPER ElKOURI, HOW ARBITRATION WORKS (Marlin M. Volz \& Edward P. Goggin eds., 5th ed. 1997); DENNIS R. NOLAN, LABOR AND EMPLOYMENT ARBITRATION IN A NUTSHELl (1998).

12 Circuit City Stores, Inc. v. Adams, 121 S. Ct. 1302 (2001); see generally RICHARD A. BALES, COMPULSORY ARBITRATION: THE GRAND EXPERIMENT IN EMPLOYMENT 17 (1997).

139 U.S.C. $\$ 2$ (1994 \& Supp. 2000).

14 H.R. REP. No. 68-96, at 2 (1924). 
"motivated, first and foremost, by a congressional desire to enforce agreements into which parties had entered."15

A plaintiff, who sues despite an arbitration agreement with the defendant, is in breach of that agreement. That agreement will be enforced, if the defendant so requests, by a stay of the plaintiff's lawsuit. ${ }^{16}$ By staying the litigation, a court effectively orders the plaintiff to perform the agreement to arbitrate. If the plaintiff is to receive any remedy, the plaintiff will have to pursue it in arbitration, rather than litigation. The only way for the plaintiff to litigate, rather than arbitrate, is to show that a ground "for the revocation of any contract" applies to the arbitration agreement. ${ }^{17}$ In other words, the plaintiff must prove a contract-law defense such as misrepresentation, duress, or unconscionability. ${ }^{18}$ In sum, the FAA embodies a contractual approach to arbitration law. Successful challenges to arbitration must find their basis in contract law, not some other source of law. ${ }^{19}$

The FAA's contractual approach applies to employees' agreements to arbitrate, just as it applies to any other party's agreement to arbitrate. ${ }^{20}$ And it applies regardless of the substantive law claims (causes of action) involved. ${ }^{21}$ Thus, an employee's statutory discrimination claim, for example, will be sent to arbitration rather than litigation, ${ }^{22}$ unless the employee can

15 Volt Info. Scis., Inc. v. Bd. of Trs., 489 U.S. 468, 474 (1989) (quoting Dean Witter Reynolds, Inc. v. Byrd, 470 U.S. 213, 220 (1985)).

169 U.S.C. $\S 3$ (1994 \& Supp. 2000).

179 U.S.C. $\$ 2$.

18 MACNEIL ET AL., supra note 11 , at $\S 19$. The application of these defenses to arbitration is complicated by the separability doctrine. Id. at $\S 15$; Ware, supra note 11 , at 128-38.

19 Stephen J. Ware, Arbitration and Unconscionability after Doctor's Associates, Inc. v. Casarotto, 31 WAKE FOREST L. REV. 1001, 1002-06 (1996); see also Stephen J. Ware, Consumer Arbitration as Exceptional Consumer Law, 29 MCGEORGE L. REV. 195, 195 (1998) (defending the contractual approach).

${ }^{20}$ Transportation workers, however, are exempted from the FAA. Circuit City Stores, Inc. v. Adams, 121 S. Ct. 1302 (2001); see also 9 U.S.C. § 1 (1994 \& Supp. 2000) ("nothing herein contained shall apply to contracts of employment of seamen, railroad employees, or any other class of workers engaged in foreign or interstate commerce.").

21 MACNEIL ET AL., supra note 11 , at $\S 16$; STEPHEN J. WARE, ALTERNATIVE DisPUTE RESOLUTION $\$ \S 2.27 \& 2.28$ (2001).

22 Gilmer v. Interstate/Johnson Lane Corp., 500 U.S. 20, 20 (1991); see also MACNEIL ET AL., supra note 11, at § 16.5; WARE, supra note 21 , at $\S 2.28$ \& n.314. 
prove a contract-law ground for challenging the arbitration agreement. The basic rule of employment arbitration law then, is that employees' arbitration agreements are enforced according to the standards of ordinary contract law. Because this rule is embodied in Gilmer and lower court cases applying and extending it, this article refers to it as the "Gilmer rule."23

The Gilmer rule is very controversial. Gilmer opponents generally take one of two positions. The more extreme Gilmer opponents would make employees' pre-dispute arbitration agreements unenforceable. ${ }^{24}$ The more moderate Gilmer opponents would make such agreements unenforceable unless the arbitration contains procedures not typically found in arbitration outside the employment context. ${ }^{25}$ Both the extreme and the moderate

${ }^{23}$ See supra note 22. The Supreme Court's majority opinion in Gilmer maintained that Gilmer was technically not an employment case. 500 U.S. at 25 n.2. Gilmer enforced an employee's agreement to arbitrate age discrimination claims. Id. at 35. The parties to the arbitration agreement, however, were not the employee and employer. Id. at $25 \mathrm{n} .2$. Rather the parties were the employee and various securities exchanges. The employer was a member of the securities exchanges and, as a condition of membership, was required by the exchanges to hire for certain jobs only employees who signed the exchanges' arbitration agreement covering disputes between the employee and employer. In effect, then, an agreement to arbitrate was a condition of employment.

24 While this position is "extreme" in giving as little weight as possible to employee consent, this position is not "extreme" in the sense of having few advocates. Many thoughtful scholars hold this position. See, e.g., Paul D. Carrington \& Paul Haagen, Contract and Jurisdiction, 1996 SUP. CT. REv. 331; Sarah Rudolph Cole, Incentives and Arbitration: The Case Against Enforcement of Executory Arbitration Agreements Between Employers and Employees, 64 UMKC L. REV. 449 (1996); Katherine Van Wezel Stone, Mandatory Arbitration of Individual Employment Rights: The Yellow Dog Contract of the 1990s, 73 DENV. U. L. REV. 1017 (1996). Cf. Jean Sternlight, Panacea or Corporate Tool?: Debunking the Supreme Court's Preference for Binding Arbitration, 74 WASH. U. L.Q. 637, 642-43 (1996) ("[I]t is critical to distinguish between commercial arbitration voluntarily agreed to by parties of approximately equal bargaining power, and commercial arbitration forced upon unknowing consumers, franchisees, employees or others through the use of form contracts.").

Others who oppose enforcement of employee's pre-dispute arbitration agreements include the Equal Employment Opportunity Commission and the National Labor Relations Board.

25 The leading case in this regard is Cole v. Burns International Security Services, 105 F.3d 1465 (D.C. Cir. 1997). Cole did enforce an employee's agreement to arbitrate statutory employment discrimination claims, but only because

the arbitration arrangement (1) provides for neutral arbitrators, (2) provides for more than minimal discovery, (3) requires a written award, (4) provides for all of the types of relief that would otherwise be available in court, and (5) does not require employees to pay either unreasonable costs or any arbitrators' fees or expenses as a 
Gilmer opponents oppose the contractual approach to employment arbitration embodied in Gilmer. Therefore, this article will make no further distinctions between extreme and moderate alternatives to the 'Gilmer rule, and will focus on the arguments for and against the Gilmer rule itself.

The controversy surrounding the Gilmer rule has focused on the arbitration of statutory discrimination claims. ${ }^{26}$ There are other claims sent to arbitration under the Gilmer rule. These include common law claims and statutory claims involving financial matters, rather than discrimination. ${ }^{27} \mathrm{But}$ sending these claims to arbitration has not been nearly as controversial as sending discrimination claims to arbitration. The participants in the employment arbitration debate seem to be most passionate about, and have the most at stake in, the arbitration of statutory discrimination claims in particular. Thus an analysis of employment arbitration law must include an analysis of employment discrimination statutes.

\section{EFFECTS OF AN EMPLOYMENT DISCRIMINATION STATUTE}

\section{A. Introduction}

The most important employment discrimination statutes include Title VII of the Civil Rights Act of 1964 (Title VII), 28 the Americans with Disabilities Act of 1990 (ADA), ${ }^{29}$ and the Age Discrimination in Employment Act of $1967 . .^{30}$ Much of the literature on the effects of these statutes is well summarized and synthesized by Christine Jolls in her recent article, Accommodation Mandates. ${ }^{31}$ This section (Section III) briefly

condition of access to the arbitration forum.

Id. at 1482. Numbers 2 and 5 are the innovations here, because numbers 1,3 , and 4 are generally found in commercial arbitration.

${ }^{26}$ Green, supra note 8, at 407 n.25, 410 n.30 (citing commentators); Ware, supra note 11 , at $101 \mathrm{n} .92$.

${ }^{27}$ See, e.g., Montes v. Shearson Lehman Bros., 128 F.3d 1456, 1457 (11th Cir. 1997) (arbitration of claim for overtime pay under Fair Labor Standards Act).

2842 U.S.C. $\S \S 2000 \mathrm{e}-17$ (1994 \& Supp. 2000).

2942 U.S.C. $\S \S 12101-12102,12201-12213$ (1994 \& Supp. 2000).

3029 U.S.C. $\S \S 621-34$ (1994 \& Supp. III 1997, Supp. IV 1998).

31 Christine Jolls, Accommodation Mandates, 53 STAN. L. REV. 223 (2000) [hereinafter Jolls, Accommodation Mandates]. A modified version of this article is available online. Christine Jolls, Accommodation Mandates and Antidiscrimination Law, at http://www.law.harvard.edu/programs/olin_center/papers/pdf/286.pdf (last visited April 11, 2001) [hereinafter Jolls, Online Accommodation Mandates]; see also Christine 
summarizes the framework constructed by Jolls. Section IV of this article extends Jolls's framework to employment arbitration.

\section{B. Universal Employment Mandates}

Consider first a statute requiring all employers to provide a certain benefit to all employees. Social Security can serve as an example of this sort of mandated benefit because nearly all employers in the United States are subject to a Social Security payroll tax. This mandate, in the standard economic model, causes wages to fall because the mandated benefit increases the supply of labor at any given wage and decreases the demand for labor at any given wage. ${ }^{32}$ Much of the cost of this mandated benefit is, in the economic model, paid for by employees in the form of lower wages. ${ }^{33}$ Not all of the cost of the mandated benefit is necessarily paid for by employees, however. Some of the cost may be paid for by employers, in the form of lower profits, and by consumers, in the form of higher prices. ${ }^{34}$ The extent to which the cost is borne by (1) employees, (2) employers, and (3) consumers is determined by the elasticity of supply and demand in the ultimate product markets and in the markets for the factors of production, labor and capital. ${ }^{35}$

For most employers, labor and capital are, to some extent, substitutes for each other. Therefore, increases in the cost of labor typically cause employers to use less labor and more capital. ${ }^{36}$ This shift from labor to capital causes employers' total production costs to rise (except in the rare case when labor and capital are perfect substitutes for each other). ${ }^{37}$ These

Jolls, Antidiscrimination and Accommodation (2001) (unpublished manuscript, on file with author) [hereinafter Jolls, Antidiscrimination]; Christine Jolls, Hands-Tying and the Age Discrimination in Employment Act, 74 TEX. L. REV. 1813 (1996).

32 Lawrence H. Summers, Some Simple Economics of Mandated Benefits, 79 AM. ECON. REV. 177 (1989). The term "wage" as used in this article includes the value of non-wage compensation as well.

33 Jolls, Accommodation Mandates, supra note 31, at 233-40.

34 Id. at 239.

35 RANDALl K. FILER ET AL., THE ECONOMICS OF WORK-AND PAY 226-28 (6th ed. 1996).

36 E.g., id. at 150-58; DANIEL S. HAMERMESH \& AlBERT REES, THE ECONOMICS OF WORK AND PAY 99-102 (3d ed. 1984); see generally JAMES D. GWARTNEY \& RICHARD L. STROUP, ECONOMICS: PRIVATE AND PUBlic CHOICE 655-63 (7th ed. 1995).

37 HAMERMESH \& REES, supra note 36, at 110 ("The impact of the wage increase on costs per unit of output will be minimized by substitution in production, but this will not 
higher production costs are, in competitive product markets, completely passed along to consumers. ${ }^{38}$ In non-competitive product markets, i.e., those in which firms (employers) are earning economic profits, only some of the higher production costs are passed along to consumers, with the rest absorbed by employers in the form of lower profits. ${ }^{39}$

With respect to universal employment mandates like Social Security, available empirical data confirms the economic model's prediction that much, but not all, of the mandate's cost is paid by employees in the form of lower wages. ${ }^{40}$

\section{Targeted Employment Mandates}

\section{Generally}

In contrast to universal employment mandates like Social Security, other statutory employment mandates are targeted to certain employees. These statutes are, as Christine Jolls puts it, "directed to discrete groups of workers, such as the disabled, [and] are intended to accommodate the unique needs of those workers."41 As an example of such a statute, the following pages use the ADA, but the reasoning also applies to Title VII and other employment discrimination statutes. ${ }^{42}$

ordinarily prevent some rise in unit costs.").

38 FILER ET AL., supra note 35, at 226 ("Of course, if the industry is competitive, profits before and after the [social security] tax must be zero, and the true division is between the portion of the tax born by the worker and the portion born by the consumer through higher prices."); HAMERMESH \& REES, supra note 36, at 110 ("In a competitive industry in the long run all firms are earning zero economic profits (just covering the opportunity cost of all inputs). Thus none of the increase in total unit costs can be absorbed by profits; it will all be passed on product prices.").

39 FILER ET AL., supra note 35, at 226-28; HAMERMESH \& REES, supra note 36, at 110.

40 See FILER ET AL, supra note 35, at 227 n.4; Patricia M. Anderson \& Bruce D. Meyer, The Effects of Firm Specific Taxes and Government Mandates with an Application to the U.S. Unemployment Insurance Program, 65 J. PUB. ECON. 119, 120 (1997); Jonathan Gruber \& Alan B. Krueger, The Incidence of Mandated EmployerProvided Insurance: Lessons from Workers Compensation Insurance, TAX POL'Y \& ECON. (1991).

41 Jolls, Online Accommodation Mandates, supra note 31, at 1.

42 Some see the ADA as significantly different from other employment discrimination statutes (like Title VII) because the ADA contains both an accommodation mandate and an anti-discrimination provision, while other statutes contain only an anti- 
The ADA creates a protected class of individuals who have an "impairment that substantially limits one or more ... major life activities," have a record of such an impairment, or are regarded as having such an impairment. ${ }^{43}$ The ADA protects this class of disabled individuals through an accommodation mandate, ${ }^{44}$ and a set of anti-discrimination provisions. ${ }^{45}$

One might expect that protected-class employees pay (in the form of lower wages) for the ADA, just as all employees pay (in the form of lower wages) for Social Security. ${ }^{46}$ There are, however, two important differences between targeted mandates, like the $\mathrm{ADA}$, and universal mandates, like Social Security. The first important difference is simply that targeted mandates are targeted. These mandates directly affect the supply of, and demand for, labor of protected-class employees only, not all employees as in the case of a universal mandate. ${ }^{47}$ The second important difference is that targeted mandates are accompanied by legal prohibitions on discrimination. These anti-discrimination provisions prohibit employers from paying less to

discrimination provision, without any accommodation mandate. See, e.g., Pamela S. Karlan \& George Rutherglen, Disabilities, Discrimination, and Reasonable Accommodation, 46 DUKE L.J. 1, 2-3, 8-9 (1996).

Jolls provides important "reasons for viewing accommodation mandates as similar to, rather than fundamentally distinct from, antidiscrimination law." Jolls, Online Accommodation Mandates, supra note 31, at 71. Both accommodation mandates and anti-discrimination provisions: (1) increase the willingness of protected-class employees to supply labor at any given wage, and (2) increase the employer's costs of employing protected-class employees. Id. at 16-24, 72-73. Like accommodation mandates, antidiscrimination provisions impose on the employer "real financial costs associated with a particular group of workers." Id. at 7. One of these costs is the risk of a suit for every adverse outcome (not just every termination) suffered by a protected-class employee. Id. at 19-21. Furthermore, anti-discrimination provisions themselves impose accommodation mandates under "disparate-impact" caselaw. Id. at 21-24, 76-77. These points are developed in Jolls, Antidiscrimination, supra note 31.

To reiterate, both accommodation mandates and anti-discrimination provisions increase the employer's costs of employing protected-class employees. That point is the basis for this article's reasoning about how those costs may be passed on to consumers and non-protected-class employees and how those costs may be reduced by arbitration, i.e., the Gilmer rule. In sum, this article's reasoning applies to anti-discrimination provisions as it applies to accommodation mandates because both increase the employer's costs of employing protected-class employees.

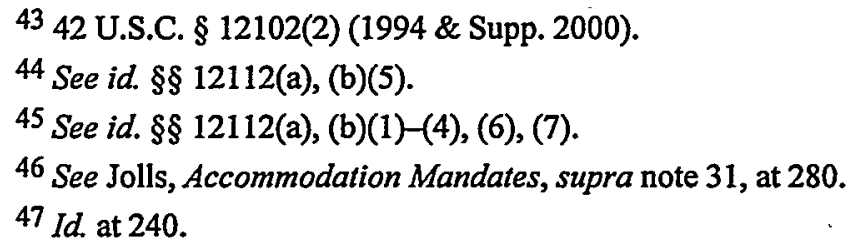


protected-class employees or refusing to hire or retain protected-class employees. ${ }^{48}$ These prohibitions, if enforced sufficiently to be binding on employers, prevent the drop in protected-class wages or employment levels that would otherwise be caused by the targeted mandate.

\section{Binding and Non-Binding Anti-Discrimination Provisions}

. If anti-discrimination prohibitions are enforced sufficiently to bind employers, i.e., employers cannot lower the wages or employment levels of protected-class employees, then all employees pay (in the form of lower wages) for the targeted mandate. ${ }^{49}$ In other words, the targeted employment mandate confers financial benefits only on protected-class employees, but the cost of this mandate is spread among all employees in and out of the protected class. $^{50}$

As discussed above, not all the cost of the mandate is necessarily paid for by employees. ${ }^{51}$ Some of the cost may be paid for by employers, in the form of lower profits, and by consumers, in the form of higher prices. ${ }^{52} \mathrm{But}$ to the extent the cost of a targeted mandate is paid for by employees, it is paid for by all employees-both those in the protected class and those out of it. In short, targeted employment mandates redistribute from employees outside the protected class to those in the protected class. ${ }^{53}$

This redistribution does not occur, however, if anti-discrimination prohibitions fail to bind employers, i.e., if employers can lower the wages or

$48 I d$. at 241 .

49 Id. at $264-65$.

50 Notice that this article's implicit baseline is the absence of the employment statute. Starting with that baseline leads one to see the statute as conferring "benefits" on protected-class employees. An alternative baseline would see the absence of the statute as conferring benefits on non-protected-class employees. Under this alternative baseline, the statute might be seen, not as conferring benefits on protected-class employees, but as removing the benefit previously held by non-protected-class employees.

This article uses the baseline that sees the statutes as conferring "benefits" because (1) this is common usage, at least with respect to Social Security and workers' compensation and other universal employment "benefits," and (2) Jolls uses that baseline. Jolls, Accommodation Mandates, supra note 31, at 225 (using the word "benefits" to describe workers' compensation and family leave).

51 See supra notes 32-40 and accompanying text.

52 See id.; Jolls, Accommodation Mandates, supra note 31, at 239.

53 Jolls, Accommodation Mandates, supra note 31, at 248. 
employment levels of protected-class employees. ${ }^{54}$ In this situation only protected-class employees pay (in the form of lower wages or employment levels) for the targeted mandate. Jolls provides extensive analysis, and reviews empirical evidence, indicating the extent to which antidiscrimination provisions bind employers in the contexts of race, sex, and disability. 55 She concludes that the extent to which anti-discrimination provisions bind employers varies with the context. ${ }^{56}$ In other words, the degree to which targeted employment mandates redistribution from nonprotected-class employees to protected-class employees varies with the context.

\section{Conclusion}

As just noted, targeted employment mandates are, in varying degrees, paid for by people other than protected-class employees. It is worth recapping how this occurs. Initially, the cost of targeted.mandates is borne by the employer because the costs of having certain employees rise. ${ }^{57}$ These costs may be borne entirely by employers (in the form of lower profits) or they may be passed onto consumers (in the form of higher prices) or to employees outside the protected class (in the form of lower wages). ${ }^{58}$ Whether any of these pass-ons occur depends on the supply and demand in

\section{Id. at $255-63$.}

55 Studies tend to indicate that the ADA reduces the employment levels of protected-class employees, id. at $276-78$, and this is consistent with Jolls' view that "there are unlikely to be binding restrictions on employment differentials between disabled and nondisabled workers." Id. at 275 (emphasis in original). Studies also tend to indicate that employment mandates targeted to women employees tend to reduce the wages of women employees, id. at 286-88, 290-96, and this is consistent with Jolls' view that there is "substantial occupational segregation by sex" in employment markets, id. at 283 , and such segregation generally makes prohibitions on sex-based wage differentials non-binding. Jolls, Online Accommodation Mandates, supra note 31, at 4548. Finally, studies tend to indicate that, in the context of race, Title VII raises both the wages and employment levels of protected-class employees, $i d$. at 71 , and this is consistent with Jolls' view that prohibitions on wage and employment-level discrimination are more likely to be binding in the context of race, than in the contexts of sex and disability. Id. at 69. These points are developed in Jolls, Antidiscrimination, supra note 31.

56 See supra note 55.

57 See supra text accompanying note 54 .

58 See supra text accompanying note 55-57. 
the relevant markets for labor, for capital, and for whatever goods this workplace produces. .99

\section{EFFECTS OF EMPLOYMENT ARBITRATION}

\section{A. Introduction}

The previous section of this article summarized Christine Jolls' framework for analyzing the effects of employment discrimination statutes. This section extends that framework to employment arbitration to describe the effects of the Gilmer rule. Recall that the Gilmer rule makes an employee's agreement to arbitrate enforceable "save upon such grounds as exist at law or in equity for the revocation of any contract.".60 The Gilmer rule permits employers to make an employee's agreement to arbitrate a condition of employment. Employers can tell employees "sign this or you're fired," and can tell prospective employees "sign this or you don't get the job." An employee's agreement to arbitrate under these circumstances is generally enforceable under the Gilmer rule. ${ }^{61}$

Who benefits from the enforcement of these agreements? Apparently, the employers that use them benefit. Otherwise, why would these employers insist on arbitration agreements with their employees? It is possible, of course, that these employers are acting against their own interests by using arbitration agreements. ${ }^{62}$ Similarly, it is possible that employers that choose

59 See supra text accompanying notes 36-39.

609 U.S.C. $\$ 2$ (1994 \& Supp. 2000).

${ }^{61}$ See Ware, supra note 11 , at 120-38. This leads Gilmer opponents to characterize much employment arbitration as "imposed" or "forced" upon employees by employers. See, e.g., Jean R. Sternlight, Mandatory Binding Arbitration and the Demise of the Seventh Amendment Right to a Jury Trial, 16 OHIO ST. J. ON DISP. RESOL. 669 (2001). It leads Gilmer opponents to reject the idea that employees have "agreed" or "consented" to arbitration. See, e.g., Miriam A. Cherry, Note, Not-So-Arbitrary Arbitration: Using Title VII Disparate Impact Analysis to Invalidate Employment Contracts that Discriminate, 21 HARV. WOMEN'S L.J. 267, 269 n.9 (1998). The concepts of consent and coercion are important, complex, and rhetorically powerful. For these reasons, scholars using these concepts should carefully define their terms. See, e.g., Ware, supra note 11, at 108-13 (defining terms); see also id. at 103-38 (arguing that only one change in the law, repeal of the separability doctrine, is needed to ensure that employment arbitration is voluntary and consensual).

62 The thesis of one article is that "mandatory arbitration is a disadvantage for large employers in terms of overall costs and outcomes when compared to the courts." Green, supra note 8, at 401 n.; see also Cherry, supra note 61, at 269 n.10. 
not to use these agreements are acting against their own interests. Given the variety of employers and their situations, it seems likely that insisting on arbitration agreements is in the interests of some employers, but not others. This article will assume that those employers that insist on arbitration agreements as a condition of employment are doing so because those employers benefit from those agreements. ${ }^{63}$

Consider the possible sources of these benefits to the employer. One possible source is that comparable cases lead to lower awards in arbitration than in litigation. ${ }^{64}$ These lower expectations would then be reflected in lower settlements, ${ }^{65}$ and in fewer cases being brought in the first place. ${ }^{66}$ All of this would reduce payments by employers. There would be fewer cases in which they pay at all, and of those cases that are brought, employers would (on average) pay less in both those cases resolved by adjudication and those resolved by settlement.

A second possible source of arbitration's benefits to the employer is that even if the amount of awards is identical in arbitration and litigation, the employer's cost of getting to the award is lower in arbitration. In other words, the employer's process costs are generally lower in arbitration than in litigation. The employer's process costs include the time and legal fees spent on pleadings, discovery, motions, trial or hearing, and appeal. If these costs are lower in arbitration than in litigation then arbitration benefits employers

63 Testing this assumption would require a researcher to obtain from employers ordinarily confidential data about their experiences before and after adopting arbitration. That would include data about all employee disputes and their resolution, including the amounts of any settlement payments and the time and other resources spent resolving all employment disputes whether or not a claim was asserted in arbitration or litigation. Even with this data, a researcher still would not know whether any change in the employer's experience was caused by adoption of arbitration or by unrelated factors that changed around the same time. See BALES, supra note 12, at 102-14, for a summary of one employer's experience.

64 This might occur for any number of reasons. For example, arbitration's rules regarding evidence and discovery may be more favorable to employers than litigation's rules on those matters, or arbitrators may tend to attach a lower dollar amount to employee's injuries than jurors do.

65 This is the alternative dispute resolution (ADR) axiom that settlement negotiations occur in "the shadow of the law." See Robert H. Mnookin \& Lewis Kornhauser, Bargaining in the Shadow of the Law: The Case of Divorce, 88 YALE L.J. 950,968 (1979) ("the outcome that the law will impose if no agreement is reached gives each [party] certain bargaining chips-an endowment of sorts.").

${ }^{66}$ Lower expected awards, all else being equal, make plaintiffs (and plaintiffs' lawyers on contingency fees) less likely to bring claims at all. 
even if the results (damages and other remedies) of arbitration are identical to those of litigation. ${ }^{67}$

\section{B. Lower Awards}

Consider first the effects of the Gilmer rule if all arbitration's benefits to the employer come from lower awards than in litigation. This is plainly a cost to protected-class employees because they win less on their claims, and that will be reflected in the settlement value of their claims and in the deterrent effect of encouraging compliance with the law. ${ }^{68}$ Conversely, the employer benefits from all this because the employer pays less. But some of those benefits may be passed onto consumers or to employees. That will depend on the supply and demand in the relevant markets for labor, capital, and whatever goods the workplace produces. ${ }^{69}$

The analysis in the previous paragraph is the flip side of the analysis (in the previous section) of the effects of an employment discrimination statute. ${ }^{70}$ That is because if arbitration benefits the employer solely by reducing awards in comparable cases then arbitration has the opposite effect of the statute creating the targeted employment mandate. Arbitration undoes, to some extent, the effects of the employment discrimination statute if arbitration benefits the employer solely by reducing awards in comparable cases.

\section{Lower Process Costs}

Now consider the effects of the Gilmer rule if all arbitration's benefits to the employer come from lower process costs. In other words, assume that

67 There may be other possible sources of arbitration's benefits to the employer, (e.g., confidentiality) but they seem small enough to justify the working assumption that these two benefits (lower awards and lower process costs) are the only possible benefits. In other words, the assumption underlying the rest of this article is that employers who insist on arbitration as a condition of employment benefit from (1) lower awards than in litigation, (2) lower process costs than in litigation, or (3) a combination of the other two.

The economics of employment arbitration agreements is also discussed in Keith $\mathrm{N}$. Hylton, Agreements to Waive or to Arbitrate Legal Claims: An Economic Analysis, 8 SUP. CT. ECON. REv. 209 (2000) and Keith N. Hylton, The Lanv and Economics of Agreements to Arbitrate Employment Claims (forthcoming).

68 See supra text accompanying note 55.

${ }^{69}$ See supra text accompanying note 61.

${ }^{70}$ See supra Part III.C. 
comparable cases get the same award or the same result in arbitration as in litigation but the employer's costs of getting to that result are lower in arbitration. These lower process costs benefit the employer. And some of these benefits may be passed on to consumers or to employees. ${ }^{71}$ In other words, the employer's lower process costs benefit some or all parties while harming no one, except those (like lawyers) who sell process. ${ }^{72}$

To see this point another way, imagine that, instead of paying lawyers to litigate employment-discrimination cases, the employer could wave a magic wand that would generate exactly the results of litigation but at zero cost in lawyers' fees. This magic wand would benefit (or at least not harm) every non-lawyer, including protected-class employees. If all arbitration's benefits to the employer come from lower lawyers' fees then arbitration differs from the magic wand only insofar as arbitration merely lowers employers' lawyers' fees, while the magic wand eliminates them entirely. ${ }^{73}$

71 Whether such pass-ons occur will depend on the factors mentioned earlier. See supra notes 35-36.

72 The analysis in the text deals only with the employer's process costs, such as the employer's lawyer's fees. The employee's process costs, including the employee's lawyer's fees, can be analyzed separately. In employment-discrimination cases, the employee typically hires a lawyer on a contingency-fee basis and prevailing plaintiffs generally have the right to have their lawyer's fees paid by the defendant. See ROTHSTEN ET AL., supra note 10 , at $\S 2.32$ ("The ordinary procedure for the computation of attorneys' fees is the calculation of the lodestar. The lodestar is the amount representing the multiplication of the number of hours spent on the case times the hourly rate."); see, e.g., Venegas v. Mitchell, 495 U.S. 82, 84 (1990).

To the extent the employee's lawyer's fees are paid by the employer, then those fees can be analyzed much like the employer's lawyer's fees are analyzed in the text. (To the extent arbitration reduces lawyer's fees, the only harm is to lawyers.) There is, however, a wrinkle. If awards in arbitration are the same as in litigation, but employees' lawyer's fees are lower in arbitration (because fewer lawyer-hours are required) then arbitration may be less attractive than litigation to employees' lawyers. Whether fewer lawyer-hours per case are attractive to employees' lawyers depends on the contingent fee percentage, the probability of winning, and alternative uses for the employee's lawyer's time. If this factor makes arbitration less attractive to employees' lawyers, then this harms employees by reducing the supply of lawyers willing to bring these cases.

73 The foregoing analysis of lawyers' fees applies equally to other process costs, such as the costs of expert witnesses, court reporters and stenographers, or travel to depositions. 


\section{Conclusion}

This section has shown that the source of employment arbitration's benefit to the employer matters. If the only source is lower awards in comparable cases then the Gilmer rule undoes, to some extent, the effects of the employment discrimination statute. While this benefits employers and, perhaps, consumers and employees outside the protected class, it harms protected-class employees. ${ }^{74}$ In contrast, if the only source of employment arbitration's benefit to the employer is lower process costs then the Gilmer rule benefits some or all parties and harms no one, except those (like lawyers) who sell process.

The foregoing analysis reveals the theories behind the rhetoric of each side in the employment arbitration debate. When opponents of the Gilmer rule accuse that rule of undercutting employment-discrimination statutes, they are espousing the theory that employment arbitration benefits employers by lowering awards. When proponents of the Gilmer rule praise that rule as helping everyone but lawyers, they are espousing the theory that employment arbitration benefits employers by lowering process costs. Both theories are plausible. And it may well be that both theories are, to some extent, correct because arbitration both lowers awards in comparable cases and lowers process costs in comparable cases.

\section{EMPIRICAL STUDIES}

\section{A. Introduction}

Some empirical studies of employment arbitration address the relative levels of awards and process costs in arbitration and litigation. These studies may be somewhat probative in determining which of the two aforementioned theories is correct. That is, these studies may be somewhat probative in determining: (1) whether Gilmer opponents are correct that arbitration

\footnotetext{
74 See Cherry, supra note 61, at 298.

Allowing employers to require waivers of antidiscrimination litigation rights as a condition of employment [i.e., enforcing employees' arbitration agreements, ] undermines the purposes of Title VII by creating a disproportionate effect on potential victims of discrimination-women and people of color. Despite its facial neutrality, an employer's imposition of a pre-dispute mandatory arbitration contract constitutes a special deterrent for women and people of color from accepting a position in that workplace.
} Id. 
lowers awards in comparable cases, and (2) whether Gilmer proponents are correct that arbitration lowers process costs in comparable cases. These studies, however, are not conclusive and should be cited with care.

\section{B. The Repeat-Player Effect and Those Who Make Too Much of It}

The best known studies of employment arbitration, by Lisa Bingham, devote little attention to the relative levels of awards and process costs in arbitration and litigation. ${ }^{75}$ Instead, Bingham emphasizes her finding that employers who are repeat-players at arbitration do better in arbitration than employers who arbitrate only once. ${ }^{76}$ Some Gilmer opponents cite this "repeat player bias" to impugn the neutrality of "arbitrators who depend for their livelihood on repeat business."77 Gilmer opponents also theorize that the repeat-player effect may be caused by repeat-players' advantage in

75 Bingham studied employment arbitration administered by the American Arbitration Association in the early 1990s. See generally Lisa B. Bingham, On Repeat Players, Adhesive Contracts, and the Use of Statistics in Judicial Review of Employment Arbitration Awards, 29 MCGEORGE L. REV. 223 (1998) [hereinafter Bingham, On Repeat Players] (studying 1993-1995 arbitrations); Lisa B. Bingham, Employment Arbitration: The Repeat Player Effect, 1 EMP. RTS. \& EMP. POL'Y J. 189 (1997) [hereinafter Bingham, The Repeat Player Effect] (studying 1993-1994 arbitrations); Lisa B. Bingham, Emerging Due Process Concerns in Employment Arbitration: A Look at Actual Cases, 47 LAB. L.J. 108 (1996) [hereinafter Bingham, Emerging Due Process Concerns] (studying 1993 arbitrations); Lisa B. Bingham, Is There a Bias in Arbitration of Nonunion Employment Disputes? An Analysis of Actual Cases and Outcomes, 6 INT'L J. CONFLICT MGMT. 369 (1995) (studying 1992 arbitrations).

76 Bingham, On Repeat Players, supra note 75, at 238-39; Bingham, The Repeat Player Effect, supra note 75, at 205-10; Bingham, Emerging Due Process Concerns, supra note 75, at 115 .

${ }^{77}$ Letter from John Vail, American Trial Lawyers Association, to the United States Department of Commerce and Federal Trade Commission 4 (Mar. 21, 2000), available at http://www.ftc.gov/bcp/altdisresolution/comments/vail.pdf; see also Cherry, supra note 61 , at 269 n.8 (" $[\mathrm{A}] \mathrm{rbitration}$ companies, for the sake of their own profit margins, may abandon fair procedural protections and instead cater to the employers who have hired them to perform a service."). Sarah Rudolph Cole makes a slightly different, but related, point:

Economic coercion clearly plays some role in a system where an arbitrator who regularly finds in favor of complaining employees may expect that the employer will be reluctant to rehire him in the future. This perverse incentive does not exist in commercial or labor arbitration because both parties are repeat players.

Cole, supra note 24 , at $478-79$. 
compiling information about potential arbitrators and their prior rulings. ${ }^{78}$ To the extent arbitrator selection is a function of party choice, ${ }^{79}$ a party has an incentive to choose arbitrators likely to rule in its favor and the repeatplayer's better information makes it more likely to succeed in predicting arbitrators' rulings. ${ }^{80}$

Bingham points out, though, that "[r]epeat player employers generally get to arbitration based on an arbitration clause in a personnel manual or employee handbook," as opposed to an individualized employment contract. ${ }^{81}$ As employers more frequently win cases stemming from a manual or handbook, Bingham "suggests that the repeat player effect may itself be a product of other factors, including the underlying agreement to arbitrate as reflected in a personnel manual, rather than an individually negotiated contract." 82 It may well be that employees who lack individuallynegotiated contracts assert claims that tend to be weaker on the merits than claims asserted by employees who have individually-negotiated contracts. ${ }^{83}$ In other words, the data may be caused, not by arbitrators favoring their paymasters or by repeat-players' greater ability to predict arbitrators' rulings, but by the weakness of claims asserted by employees who lack individually negotiated contracts.

The previous paragraph shows that, even if the Bingham studies reveal a repeat-player effect in arbitration, they do not reveal whether that effect is present when one controls for the merits of the cases. In other words, the presence of a repeat-player may make no difference in otherwise comparable cases. So the empirical evidence on a repeat-player effect is inconclusive.

The most important point about the repeat-player effect, however, is that this effect may be at least as prevalent in litigation as in arbitration. ${ }^{84}$ It is

78 Cole, supra note 24 , at $476-79$.

${ }^{79}$ It may be indirect party choice because some arbitration rules provide that the arbitration organization, rather than the parties, selects the arbitrators.

80 Bingham, On Repeat Players, supra note 75, at 240.

81 Id. at 238.

$82 \mathrm{Id}$. at 239.

${ }^{83}$ Cf. Bingham, The Repeat Player Effect, supra note 75, at 213. This is plausible if individually-negotiated contracts (which tend to be achieved only by high-level employees) tend to confer more rights on employees than personnel manuals (which tend to be take-it-or-leave-it documents distributed to a wide range of employees). As Bingham points out, "Personnel manuals are more likely to be the product of a repeat player employer unilaterally structuring the employment relationship and dismissal transaction to its best advantage." Id.

${ }^{84}$ Research revealed no published studies addressing this. If the repeat-player effect 
the comparison of arbitration and litigation that matters for an assessment of the Gilmer rule. And the many pages written about repeat players say little about this comparison. In particular, they say little about the relative levels of awards and process costs in comparable cases in arbitration and litigation.

\section{Studies Comparing Employment Arbitration and Litigation}

There are two well-known studies comparing employment arbitration with employment litigation. One study is by William Howard ${ }^{85}$ and the other is by Lewis Maltby. ${ }^{86}$ Both find that employees win a much higher percentage of their claims in arbitration than in litigation. ${ }^{87}$ While Gilmer proponents cite these findings as proof that arbitration is better than litigation for employees, ${ }^{88}$ Howard and Maltby recognize that one must consider not only how often employees win, but also how much they win. ${ }^{89}$

in arbitration is caused by differences in the merits between personnel manual cases and individual-contract cases, see supra note 83 , then one would hope and expect to find a repeat-player effect in litigation, too.

85 William M. Howard, Mandatory Arbitration of Employment Discrimination Disputes 62, 100 (1995) (unpublished Ph.D. dissertation, Arizona State University) (on file with author) (Howard studied American Arbitration Association employment arbitration from 1993 and 1994, securities Self-Regulatory Organization arbitration from February 1992 to October 1994, and employment litigation from June 1, 1992 to May 31, 1994); see also William M. Howard, Arbitrating Claims of Employment Discrimination, DISP. RESOL. J., Oct.-Dec. 1995, at 40.

${ }^{86}$ Lewis L. Maltby, Private Justice: Employment Arbitration and Civil Rights, 30 COLUM. HUM. RTS. L. REV. 29, 47-49 (1998) [hereinafter Maltby, Employment Arbitration and Civil Rights] (comparing 1994 employment litigation data with Bingham's employment arbitration data from the same year and with Bingham's 19931995 employment-arbitration data); see also Lewis Maltby, Employment Arbitration: Is It Really Second Class Justice?, DisP. RESOL. MAG., Fall 1999, at 23.

${ }^{87}$ Maltby finds that employees win $63 \%$ of their claims in arbitration and only $15 \%$ of their claims in litigation. Maltby, Employment Arbitration and Civil Rights, supra note 86, at 46. And Maltby cites other studies also finding that employees win a high percentage of their claims in arbitration. Id. at 49-50. Howard finds that employees win $68 \%$ of their claims in arbitration, Howard, Mandatory Arbitration of Employment Discrimination Disputes, supra note 85 , at 124 , and only $28 \%$ of their claims in litigation. Id. at 107.

88 See, e.g., JAMES T. RILEY, CITIZENS For A SOUNd ECON., PRotECTING THE TRIAL LAWYER MONOPOLY: THE ASSAULT ON STATE AND FEDERAL BINDING ARBITRATION, ISSUE ANALYSIS 106, at 2 (July 12, 2000), available at http://www.cse.org/informed/866.html.

${ }^{89}$ Howard, Mandatory Arbitration of Employment Discrimination Disputes, supra 
Howard and Maltby both find that employees who win in litigation win substantially more money than employees who win in arbitration. .0

Both Howard and Maltby also address the process costs of arbitration and litigation. Both conclude that process costs of arbitration are much lower. ${ }^{91}$ This conclusion supports Gilmer proponents who argue that the Gilmer rule benefits some or all parties while harming no one, except those (like lawyers) who sell process. ${ }^{92}$ The Maltby study further supports this position by combining data on arbitration's higher employee-win rates and lower awards to calculate that employees have a higher adjusted outcome in arbitration than litigation..$^{93}$ On the other hand, Howard's data, which shows

note 85, at 127; Maltby, Employment Arbitration and Civil Rights, supra note 86, at 48 .

90 Howard finds that both mean and median awards are at least three times higher in litigation than in arbitration. Howard, Mandatory Arbitration of Employment Discrimination Disputes, supra note 85, at 132. Maltby finds that winning claims in arbitration recover only $25 \%$ of the amount demanded, while winning claims in litigation recover $70 \%$ of the amount demanded. Maltby, Employment Arbitration and Civil Rights, supra note 86 , at 48 . A survey of employers who have adopted arbitration systems revealed that many employers believed that juries posed too great a risk of run-away monetary awards. See Mei L. Bickner et al., Developments in Employment Arbitration, DISP. RESOL. J., Jan. 1997, at 8, 78-79.

Because of the time-value of money, a comparison of awards in arbitration and litigation should adjust for the length of time it takes the winning employee to obtain the money. Maltby suggests that the average arbitration case is resolved in less than half the time required for civil litigation. Maltby, Employment Arbitration and Civil Rights, supra note 86, at 55 (citing Gary G. Mathiason \& Pavneet S. Uppal, Evaluating and Using Employer-Initiated Arbitration Rules and Agreements, in EMPLOYMENT DISCRIMINATION AND CIVIL RIGHTS ACTIONS IN FEDERAL AND STATE COURTS 875, 894 (1994)).

91 Howard surveyed employment lawyers. Lawyers who represent employerdefendants estimated their clients' cost of lawyers' fees, expenses, and court costs averaged $\$ 96,000$ in litigation and only $\$ 20,000$ in arbitration. Howard, Mandatory Arbitration of Employment Discrimination Disputes, supra note 85, at 142. The General Accounting Office also found that legal fees among its employer-respondents were generally lower in arbitration. U.S. GEN. ACCOUNTING OFFICE, ALTERNATE DISPUTE RESOLUTION: EMPLOYERS' EXPERIENCES WITH ADR IN THE WORKPLACE 19 (1997). Maltby suggests that legal fees in arbitration could run as little as $\$ 3,000$. Lewis $L$. Maltby, The Projected Economic Impact of the Model Employment Termination Act, 536 ANNALS AM. ACAD. POL. \& SOC. SCI., 103, 117 (1994).

92 Gilmer proponents argue that employment arbitration benefits employers by lowering process costs and some of these benefits may be passed on to consumers and employees. See supra Part III.C.2 \& 3.

93 Maltby, Employment Arbitration and Civil Rights, supra note 86, at 48-49.

The "adjusted outcome" is the total amount received by all plaintiffs in arbitration or in court-not merely those who were successful-as a percentage of their demands. 
a larger difference between arbitration and litigation awards, might lead to the opposite conclusion if a similar calculation is performed. ${ }^{94}$

\section{Warning! Use Empirical Studies with Care!}

The Howard and Maltby studies paint a picture of the relative levels of awards and process costs in arbitration and litigation. And this picture may be accurate. ${ }^{95}$ There is, however, an important reason to be skeptical about its accuracy. Empirical studies can tell us the relative levels of awards and process costs in arbitration and litigation, but that does not mean they can tell us the relative levels of awards and process costs in arbitration and litigation in comparable cases. The probative value we give to empirical studies should turn on our level of confidence that the studied cases going to arbitration are comparable to the studied cases going to litigation. ${ }^{96}$ And, in reality, nobody knows whether the cases going to arbitration are comparable

This "adjusted outcome" for arbitration-plaintiffs is eighteen percent (i.e., plaintiffs as a whole in arbitration received eighteen percent of their demands). For plaintiffs in litigation, the adjusted outcome is only $10.4 \%$.

Id. at 48.

94 Howard finds that both mean and median awards are at least three times higher in litigation than in arbitration. Howard, Mandatory Arbitration of Employment Discrimination Disputes, supra note 85, at 132.

95 of course its accuracy may be confined to the particulars of the arbitration studied. Bingham, Howard, and Maltby studied employment arbitration administered by the American Arbitration Association and securities Self-Regulatory Organizations. Nonadministered arbitration, or arbitration administered by other organizations, may differ. Even AAA and SRO arbitration may now differ from that studied by Bingham, Howard, and Maltby because of recent changes in these organizations' procedures. See Green, supra note 8, at 424-28; see Lisa B. Bingham, Employment Arbitrations Before and After the Due Process Protocol: Preliminary Evidence that Self-Regulation Makes A Difference in Alternative Dispute Resolution in the Employment Arena, in ALTERNATIVE DisPute RESOlUTION IN THE EMPLOYMENT ARENA: PROCEEDINGS OF NEW YORK UNIVERSTTY'S 53RD ANNUAL CONFERENCE ON LABOR (Samuel Estreicher ed., forthcoming 2002).

96 Cf. Carrie Menkel-Meadow, When Dispute Resolution Beget Disputes of Its Own: Conflicts Among Dispute Professionals, 44 UCLA L. REV. 1871, 1924 (1997).

In contrast to the many court-connected [ADR] program evaluations, however, there is little to no information concerning the private uses of $A D R$, in large part because developing anything close to an experimental or comparative design model is virtually impossible.

Research concerning the effects of ADR programs is especially difficult due to Id. the problems of developing control groups.... 
to the cases going to litigation. ${ }^{97}$ As Bingham points out, "there is a risk that on the merits, employment arbitration and litigation cases may be apples and oranges." 98

In other areas of study, a scholar can (to a great extent) overcome this methodological problem. Suppose, for example, that a court requires mediation of all cases with odd docket numbers, but not of cases with even docket numbers. A scholar could then compare the results of the odd cases to the results of the even cases and attribute any differences to the rule requiring mediation. With a sufficiently large sample size, we would be quite confident that the odd cases are comparable to the even cases. That is because the odd and even docket numbers are completely unrelated to anything that might plausibly affect the results of the cases.

In contrast, the selection of cases between arbitration and litigation is very different. Employment cases go to arbitration when, and only when, there is an arbitration agreement. The employers who use arbitration agreements may be systematically different from the employers who do not use arbitration agreements. It may, for example, be that employers who use arbitration agreements have better lawyers than employers who do not. Or it may be the other way around. It may be that employers who use arbitration agreements have better (or worse) human resource departments than employers who do not. It may be that employers who use arbitration agreements are more (or less) likely to have previously defended employment-discrimination claims. ${ }^{99}$ It may be that employers who use arbitration agreements have better (or worse) reputations for their treatment of employees. It may be that employers who use arbitration agreements are

97 Maltby seems to have recognized this and tried to adjust for it by expressing the employee's award as a percentage of the amount demanded in the complaint. Maltby, Employment Arbitration and Civil Rights, supra note 86, at 48-49. But comparative statistics assessing damages as a percentage of the amount demanded are themselves suspect. "Given that the fees parties pay in arbitration are based on the amount demanded, [Maltby's] numbers may reflect no more than the fact that parties in arbitration have a strong incentive to be more realistic about their initial demands than parties in court." CHRISTOPHER DRAHOZAL, COMMERCIAL ARBITRATION 1-7 (forthcoming 2001).

98 Bingham, The Repeat Player Effect, supra note 75, at 199.

${ }^{99}$ Cf. Alexander J.S. Colvin, Citizens and Citadels: Institutions, Employment Strategies, and the Adoption of Nonunion Dispute Resolution Procedures 30 (unpublished manuscript, on file with author) ("[T]he presence of nonunion arbitration procedures has a significant positive association with" two "variables representing the litigation threat": the implied contract exception to employment at will, and the percentage of employees who are female). 
more (or less) capable of paying a large verdict. ${ }^{100}$ Any of these differences might plausibly correlate with whether the employer uses arbitration agreements. And any of these differences might well affect the level of awards or the level of process costs. In sum, there are many plausible reasons to doubt that the employment cases going to arbitration are comparable to those going to litigation. 101

The essential point is simple. The very fact that one employer, but not the other, thought about employment arbitration and instituted a policy of pre-dispute arbitration agreements should not be ignored. Yet any émpirical study has to ignore it. Any empirical study has to assume that fact away.

For this reason, empirical studies are, at best, an incomplete route toward understanding the effects of the Gilmer rule. Empirical studies are vulnerable to the possibility that the studied cases going to arbitration are systematically different from the studied cases going to litigation. This will remain true as long as the law allows contracts to determine whether or not a case goes to arbitration.

\section{CONCLUSION}

Gilmer opponents assert that arbitration lowers awards in comparable cases, while Gilmer proponents assert that arbitration lowers employers'

100 Id. at 29 ("[T]he only statistically significant relationship for the size of the [employer] is a negative association with the presence of nonunion arbitration").

101 Even if the cases in which arbitration is commenced are comparable to those in which litigation is commenced, those that settle before arbitration concludes may be systematically different from those that settle before litigation concludes. For example, the standard economic analysis of settlement holds that settlement rates correlate with the cost of adjudication and the predictability of adjudication. RICHARD A. POSNER, ECONOMIC ANALYSIS OF LAW $\S 21.5$ (5th ed. 1998). If arbitration is both less costly and less predictable than litigation, then economic analysis predicts lower settlement rates in arbitration than in litigation. This is consistent with data from William Howard's survey of employment lawyers. See Howard, Mandatory Arbitration of Employment Discrimination Disputes, supra note 85, at 139 (finding a 79-84\% settlement rate in litigation and $31-44 \%$ settlement rate in arbitration). If a much lower percentage of arbitrated cases settle then one must ask whether they are a representative sample of the larger group of cases that would have settled in litigation had there been no Gilmer rule.

If cases that settle before arbitration concludes are systematically different from those that settle before litigation concludes, then a probative comparison of employment arbitration and employment litigation would have to compare the results of settlement as well as the results of adjudication. Settlement data, however, is nearly always unavailable to researchers. Howard, Mandatory Arbitration of Employment Discrimination Disputes, supra note 85 , at 131 . 
process costs in comparable cases. Either, neither, or both of these assertions may be correct. Attempts to test these assertions empirically have been inconclusive. Further empirical studies of employment arbitration will be similarly inconclusive because of the real possibility that the studied cases going to arbitration are systematically different from the studied cases going to litigation. Therefore, we should resist the temptation to call (as so many academic articles do) for "more empirical research." And we should be skeptical of both Gilmer proponents who deny the possibility that arbitration harms protected-class employees and Gilmer opponents who deny the possibility that arbitration benefits anyone other than employers. 